International Journal of Social Sciences and Humanities
Available online at http://sciencescholar.us/journal/index.php/ijssh
Vol. 2 No. 1, March 2018, pages: 147 156
e-ISSN: 2550-7001, p-ISSN: 2550-701X
http://dx.doi.org/10.29332/ijssh.v2n1.105

\title{
Implementation of Communication Ethics in Building Social Harmony
}

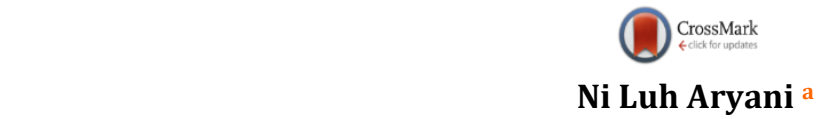

Article history: Received 10 September 2017, Accepted in revised form 20 February 2018, Approved 20 March 2018, Available online 30 March 2018

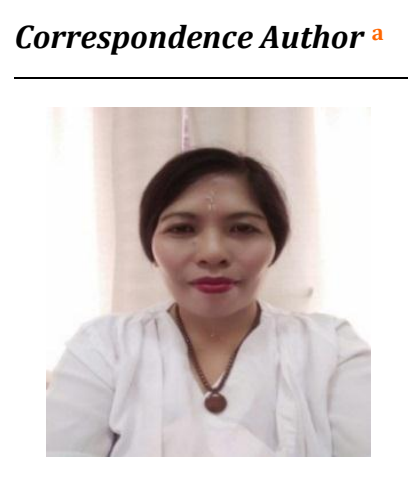

Keywords

Communication;

Dharma santhi;

Ethics;

Harmony;

Wacika parisudha;

\begin{abstract}
This research is intended to study the implementation of communication ethics in building social harmony at Banjar (Balinese community) Dharma Santhi, Labuapi Subdistrict, West Lombok Regency. This research is designed in the form of descriptive qualitative research by using case study model on social phenomenon of religion in that location. With regard to it in order to realize a harmonious religious social life one of the supporting factors is the ethics that needs to be applied in communicating, both interpersonal communication and group communication in activities related to the implementation of Hinduism. The implementation of communication ethics used as the basis of religious social life in Banjar Dharma Santhi relates to the application of the teaching of tri kaya parisudha (three things to be sanctified), especially the aspect of wacika parisudha (talking good and true). Application of communication ethics based on the teachings of Hinduism can realize a good communication, especially related to the implementation of religious life conducted by the people who are in Banjar Dharma Santhi. Communication in accordance with the teachings of wicika parisudha implemented by Hindus in the location can realize social relationships with fellow Hindus in religious ritual activities. The application of wacika parisudha teachings can also be a basis for communicating with the general public to realize harmony in religious social life.
\end{abstract}

e-ISSN : 2550-7001, p-ISSN : 2550-701X ๑ Copyright 2018. The Author. SS Journals Published by Universidad Técnica de Manabí. This is an open-access article under the CC BY-SA 4.0 license (https://creativecommons.org/licenses/by-sa/4.0/) All rights reserved.

\section{Contents}

Abstract

1. Introduction 148

2. Research Method 149

3. Results and Analysis 149 


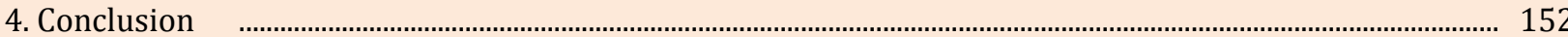

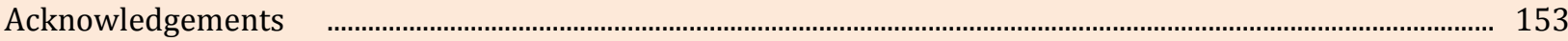

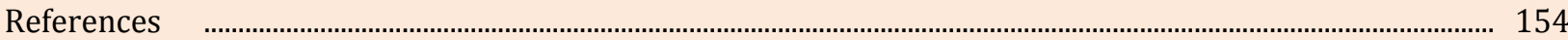

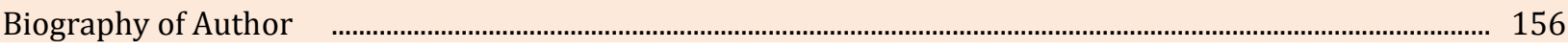

\section{Introduction}

Communication in Hindu life plays an important role in realizing relationships, both relationships between individuals and intergroup relationships in realizing social harmony. Good communication and targeted can realize the messages in accordance with the intended by the communicator to the communicant. It also applies to the contrary when the messages conveyed by the communicator to the communicant cannot be delivered with good communication raises the gap between the messenger and the recipient of the message. Gaps in the communication process can cause negative impacts, both for communicators and communicants. The phenomenon is in line with the expression Santoso and Setiansah (2010:3) that communication is a means to social interaction with human beings. Communication in everyday human life can realize happiness and also can cause unhappiness.

The above phenomenon also occurs in the social life of religious practice in Banjar Dharma Santhi, Labuapi Subdistrict, West Lombok Regency. In the Hindu life of the location, there are various kinds of communication, both vertical and horizontal. Communication in the vertical aspect is done, especially when Hindus carry out ritual activities on certain days, especially on holy days of Hinduism and on the implementation of pujawali (the implementation of religious ceremonies). The practice of ritual in relation to the holy days of Hinduism, such as Galungan, Kuningan, Purnama, Tilem, Kajeng Kliwon, and other Hindu holy days. Meanwhile, the implementation of the ritual associated with pujawali, which is carrying out a religious ceremony held at a temple owned by Hindus in Banjar Dharma Santhi. Vertical communication in the implementation of the ritual as a form of ritual communication. This ritual communication is done by Hindus who carry out religious activities with the intention of communicating with Ida Sang Hyang Widhi Wasa (God Almighty) who is believed to have an influence on human life. With regard to vertical communication in religious life according to Effendy (2002: 4) categorized as transcendent communication. Transcendent communication is communication with something "supernatural", including communicating with God. People who are praying, whether they are performing their duties as religious people.

Synergize with the above, humans as religious beings communicate with forces that are outside the boundaries of empiricism. Referring to Agus (2005:255-256) suggests that a society dominated by belief in many supernatural beings affecting life, communication-based on the sacredness of things, communications expressed in rituals and observing the things taboo, primitive tribe, is a religious communication. Religious communication is mystical, supernatural and ritualistic.

Communication in the horizontal aspect carried out by Hindus in Banjar Dharma Santhi is done with fellow human beings with certain purposes. Communication in the horizontal aspects associated with the implementation of Hinduism occurs in various forms, such as interpersonal communication, social communication, and group communication. All forms of communication aim to succeed the implementation of religious activities.

It is very important to note in the communication to realize social harmony in Banjar Dharma Santhi is to pay attention to the ethics of communicating. Communication ethics deals with the rules that must be followed in communication. The rules of communication are closely related to the teachings of Hinduism, the moral order. Morality is a Hindu religion that deals with the norms that must be followed in order to realize a harmonious life. The moral teaching in practice involves morality related to the deeds that must be done in order to realize a harmonious life. Likewise, on the contrary, there are the actions that must be avoided that can bring adverse impact on people who carry out as well as others.

In connection with the above, in order to realize harmony in religious social life in Banjar Dharma Santhi would be necessary to study the ethics of communication applied in everyday life. It is based on the consideration that the communication ethics provide the foundation for an ideal communication process so that communicators in conveying a particular message can be received quickly by the communicant. Related to that, in the communication ethics of the message delivery process can run as expected and can avoid the occurrence of gaps in the communication process. The implementation of communication ethics 
focused on this research is related to the ethics of religious communication. The ethics of religious communication in this study is based on the ethics of communication contained in the teachings of Hinduism. The ethics of communication in the teachings of Hinduism according to this research is called the moral order (Wirawan: 2018).

\section{Research Method}

This research is designed in the form of descriptive qualitative research with case study research type. The type of data required in this study is qualitative data presented in the form of narrative text from the data source and then analyzed and the conclusions are also displayed in the form of narration. This research uses the data source in the form of primary data and secondary data. Primary data were collected through observation techniques and interview techniques. This is because both techniques are used to obtain data directly in the field. Primary data in research is obtained directly through observation and interview. Observations were made by researchers directly to the field. Interviews were conducted indepth with informants selected purposively. Secondary data is data obtained through reference books that can support the research. Secondary data sources were obtained by analyzing the document sources related to the study focus in this study, such as monographs, statistical data, and other references relevant to the study focus in this study.

The data collected in this research is qualitative data in the form of narrative text according to the data collection technique used. Data were collected through three techniques, namely observation, interview, and documentation study. Observation is done by observing the events that occur in the field in accordance with the focus of this research. In doing the observations carried out the recording of the data found in the field. Interview technique is conducted by conducting in-depth interviews with a number of informants who are determined based on purposive techniques. The selection of purposive techniques is related to the purpose of this study. Documentation studies were conducted by analyzing a number of documents that support this research focus.

The technique of data analysis in this research is done through data grouping, data reduction, and data verification. Data grouping is the process of selecting data based on groups according to the formulation of the problem. Data reduction is the process of selecting and sorting the data tailored to the needs of this research focus. Verification of data is a process associated with drawing conclusions from the analysis conducted. The process of data analysis involves relevant theories to help sharpen the results of data analysis.

The results of further data analysis presented in the form of narrative text in accordance with the formulation of the problems raised in this study. Data in the form of numbers is also used as a support to strengthen the validity of the results of this study. In order to check the validity of data used techniques triangulation data, namely triangulation of data sources, triangulation method, and triangulation theory. Triangulation techniques are basically done to cross-check the data obtained so that the validity of the results of this study can be accounted for.

\section{Results and Analysis}

\subsection{Application of Communication Ethics on Religious Social Life in Banjar Dharma Santhi}

The religious social life of the Hindu community in Banjar Dharma Santhi since the past has shown the existence of a harmonious life. Based on observations in the field of harmony that occurred in the life of people in the location occurred, both internally and externally. The harmony that occurs in the internal aspect is indicated by the happening of harmony among fellow Hindus. This is demonstrated by the pattern of life that helps each other amongst fellow Hindus. Based on field data obtained that Hindus in the location is predominantly Balinese people. The harmony is also happening in overcoming the problems faced simultaneously. These events as a form of social integration between different religions. In connection with that, Khalikin (2009:135) argued that integration can be formed through the implementation of religious values that can encourage the existence of integrative community life, complement each other and prevent horizontal conflicts among people, especially on different faiths.

External harmony, which involves Hindus with other people around Banjar Dharma Santhi. Based on field data obtained that the followers of Moslem are a majority population who live in the vicinity of Banjar

Aryani, N. (2018). Implementation of Communication Ethics in Building Social Harmony. International Journal Of Social Sciences And Humanities (IJSSH), 2(1), 147-156. doi:10.29332/ijssh.v2n1.105 
Dharma Santhi. The pattern of harmony built between people who embrace Hinduism and those who embrace Islam is indicated by the presence of mutual attitudes or help each other when faced the problem. The confusion between Hindus and Muslims is indicated by the small number of conflict events occurring in the region.

The pattern of harmony in religious life occurring in Banjar Dharma Santhi as described above is supported by a number of factors. Supporting factors are one of them is the ethics in communicating. Hindu society in the Banjar (Balinese community) is very concerned ethics in everyday life. Ethics is not only applied in the aspects of communication but also in thinking and doing. The phenomenon as expressed by I Nengah Pasek stating that in everyday life is very important to conduct etiquette. Relating to that starting from thinking, speech, and doing must always be good. It is not justified to offend anyone else. The ethics relating to words cares about manners and shows a courtesy attitude in everyday life to reflect the teachings of the tri kaya parisudha (three things to be sanctified). In speaking should pay attention to the ethics of communication that starts with each individual self.

The communication ethic presented above is the manners that must be executed when communicating. The teaching of the rich tri parisudha mandates that thinking, saying, and doing should be in good and right corridors as a form of purification. Thinking good and right is called manacika parisudha, speaking good and true is called wacika parisudha, and doing good and right is called kayika parisudha. The ethical aspect of communication in the teaching of tri kaya parisudha is the practice of the teachings of wacika parisudha. The meaning of this teaching is through the implementation of wacika parisudha guiding a person to control all the utterances delivered.

In connection with the above, in religious social activities should always be maintained so that the attitude of mutual respect. The attitude of mutual respect, as expressed by I Made Mudana which in outline states that at the time of socializing by using ethics, which must be maintained is the mind and deeds. In addition, the courtesy and help each other and mutual respect among fellow God's creation must also be considered. It is also important to respect each other between religious people, maintain harmony (courtesy) in everyday life.

Based on the above narrative the use of ethics in religious social life should be a grip in order to create a harmonious life. The ethics involve thinking and doing. Thinking that is based on ethics is always thinking of positive things related to realizing harmony in religious social life. The teachings of Hinduism mandate that thinking that can bring about a better life is manacika parisudha. Meanwhile, ethics relating to deeds is about actions based on kayika parisudha, which is a good and righteous act that can realize the goodness. In everyday life when conveying something through verbal communication, as in doing socialization should always be considered ethics of communication. Communication-based on ethics taught in the teachings of Hinduism is wacika parisudha.

Building communication ethics as a foundation for the realization of harmony in the religious social aspect is based on self-awareness, as expressed by Ketut Pino Wikana which basically says that the way to build communication ethics is self-conscious, that we social beings will definitely need others, as long as we aware that we as social beings, we will definitely need communication with others. In communicating we must also respect each other, always think positive, and if there is a problem do not blame others try to always introspection.

The reciprocal relationship between one individual and another in the social life of religion, as informed by the informant above is based on self-awareness. Man as a social being in his life certainly needs others in order to maintain his existence. In connection with that, in realizing mutual relationships between one individual with another individual must be based on ways to communicate so as to avoid the emergence of things that are not desirable. Along with that in implementing ethics in the communication process as well as the existence of an appreciation of each other. Awareness that arises from within the self in doing communication-based on normative norms, of course, positive dimensions to harmony in social relations.

Building a harmonious relationship with fellow human beings associated with the teachings of Hinduism, especially relating to tri hita karana there aspect pawongan, namely maintaining good relations with fellow human beings. Aspect pawongan as one of the elements of tri kaya parisudha associated with argument Wirawan (2011:3) that the relationship between human and good human be the basis for the creation of a comfortable life, peaceful and peaceful, both outwardly or inwardly. 
The process of communicating, both among individuals and between groups in Banjar Dharma Santhi using various media. It is, as revealed by I Made Suprapta which in the outline says that communication tools commonly used to communicate in Banjar Dharma Santhi using media correspondence, with mobile intermediaries, direct communication, and communication through meetings of members of the banjar (Balinese community).

Based on the above, in the religious social life of the community in Banjar Dharma Santhi, communication is done by using a number of media. The use of media, such as correspondence, and electronic communication tools are very effective in delivering important messages in order to realize a better life. Communication in relation to religious social life is essentially related to the implementation of religious activities involving Hindus in a relatively large number. Interpersonal communication is done through the media of correspondence is a formal matter, while informally often use mobile phone media in conveying important messages that are urgent to Hindus, especially in order to carry out religious ritual activities (Pemayun: 2018).

In synergic of the above phenomenon of awareness to establish a reciprocal relationship in religious life is very important in order to realize harmony. The reciprocal relationship is based on the rules of thinking, speech, and do that based on tri kaya parisudha teaching. This requires the endeavor of each individual. Referring to Naim (2015: 133) that one of the important aspects that should be continually strived for in social life in Indonesia is harmony. Fighted because harmony can not be formed just like that. Harmony requires serious effort and willingness to guard it. The awakened harmony can be torn apart and destroyed by the waning consciousness of harmony itself (Dewi: 2018).

\subsection{Implications Implementation of Communication Ethics on Religious Social Life in Banjar Dharma Santhi}

Implications of the application of communication ethics to religious social life in Banjar Dharma Santhi, Labuapi subdistrict, West Lombok regency related to the impacts it generates. The impact is more dominant on the positive side, namely the realization of a harmonious religious social life. With regard to the application of communication ethics, especially those derived from the teachings of Hinduism, the tri kaya parisudha seeks to realize the sanctity of mind, words, and deeds, as expressed by informant, namely I Wayan Repotyasa that within the framework of Hindu religion related to behavior is related to tri kaya parisudha ie three purified behaviors. The division is manacika, wacika, and kayika parisudha. Manacika means to think good, wacika means to good speaking kayika means to do good.

The foundation of tri kaya parisudha in every activity undertaken by Hindus if applied properly and correctly can manifest the blissfulness for oneself as well as for others. The element of the tri kaya parisudha, namely wacika parisudha is the foundation of the ethics of Hindu communication to realize good communication arrangement. In this regard, informant Putu Handreyana outlines that the implementation of social communication in Banjar Dharma Santhi, in general, has been running in harmony, although no doubt there are still obstacles. This is due to the lack of understanding of unity, there are social gaps, lack of meeting intensity, lack of understanding of the functions of the banjar and the lack of social life.

Based on the above mentioned in communicating to the Hindu community in Banjar Dharma Santhi there are also obstacles faced. These constraints, a lack of understanding of the meaning of togetherness that can realize social inequality. This has implications for the intensity of meetings conducted by the community to be reduced. At the same time, when the ethics of communication have not been able to work properly, awareness of the religious social understanding implemented by banjar members will also decrease.

The weaknesses that occur in connection with communication on the banjar community is a common thing happens in every life organized. It affects the communication that occurs less effective so it can cause disharmony, as stated by informant Gede Astika who states that how to overcome the factors that cause communication in banjar less harmonious that is by not distinguish the social status of members of the banjar. Giving understanding to fellow friends, frequent meetings and seek to have a meeting place. Each member of the banjar to understand the articles of association and the household budget. Familiarize yourself with having a social soul.

Aryani, N. (2018). Implementation of Communication Ethics in Building Social Harmony. International Journal Of Social Sciences And Humanities (IJSSH), 2(1), 147-156. doi:10.29332/ijssh.v2n1.105 
The communication gap that occurs in the religious social life in Banjar Dharma Santhi as described above should be overcome by growing awareness of social soul in each individual. Differences arising from understanding in a communication process can be overcome by conducting rembug (discussion), as expressed by informant I Wayan Gede Darmadi who in the outline said that differences of opinion can be delivered with a polite word without offending other people. Perform rembug and deliberation to reach consensus. Learn to accept the opinions of others, not blame each other, and always guided by the teachings of religion.

The emergence of efforts to overcome the problems faced by members of the banjar also can not be separated from the ethics in delivering the message in a communication process. It is related to the existence of awareness to tell each other things that must be implemented, as expressed by informant I Made Suprapta which in the outline states that in this case the board and all members of the banjar can tell that the ethics performed by one of the members out of banjar statutes and bylaws and community and be re-notified to statutes and bylaws of banjar which has been agreed. Regarding the existing legal rules of the articles of association and household budget and social sanctions in the community.

Submitting the message correctly as a foundation for realizing communication ethics that can realize the delivery of messages effectively and easily accepted by the recipient of the message. Each member of the banjar should be able to realize the communication ethics properly and correctly. It is also conveyed by informant I Gusti Ketut Mas which basically reveals that in towards the ethical direction of the harmonious human resources that are a very important role to lead the direction of communication ethics. There should be openness, every decision must be discussed first. Providing an understanding of religious teachings through lectures and discussions. Must have a sense of mutual understanding in order to happen harmony.

In harmony with the above in realizing a harmonious life based on religious ethics is also presented by informant I Made Suarsa which in the outline states that to lead a harmonious ethic we must start with a healthy mental improvement. All matters can be resolved in a kinship and deliberation to reach consensus. Attitudes of mutual understanding, mutual respect, and mutual respect also must be fostered.

The application of good communication ethics is based on the awareness of mutual acceptance based on compliance. These attitudes are acknowledged by informant I Nyoman Muliarta who outlines that a condition in which two-way communication is mutually accepted and the absence of a problem from either party and communication does not create a pressure with full awareness of acceptance and adherence according to compliance. Here it is desirable to share, mutual acceptance, mutual respect both between religious people and the people of the same.

Awareness to accept each other is the foundation to realize harmony in everyday life. In this regard, people living in the midst of their social environment must be able to live a life of mutual acceptance and mutual giving. The phenomenon is also reinforced by the phrase conveyed by informant I Made Mudana which in the outline says that what is meant by the ethics of communication that is actually human as social beings will always relate to each other because true man will not be able to live alone, he will always need help or services of others. Therefore established communication, for communication can be harmoniously established then he must be ethical ie speak the words and behave well according to the guidance of religion that he believed.

Based on the above phenomenon shows that the attitudes are mutually acceptable to the differences that exist in the middle of social life. Acceptance of these differences relates to building relations between religious and interfaith believers. In connection with that, Ngurah, et al. (2006: 101-103) suggests that the internal harmony of the religious community includes harmony between fellow believers, such as among Hindus as well as other believers. Interreligious harmony includes personal with personal, family, banjar people, village, fellow adherents to the next level. Harmony among religious people is about interfaith people of different religions. Harmony in their respective lives, deserve to love each other loves, appreciate praise and honor because basically, all human beings in God's eyes are the same.

\section{Conclusion}

Based on the above study can be drawn red thread in religious social life in the Hindu community in Banjar Dharma Santhi in order to realize a harmonious life, both among fellow Hindus and with the general public of communication plays a very important role. Communications conducted by the Hindu community 
at the site are manifested in the form of verbal communication and nonverbal communication. Verbal communication is done by the Hindu community in religious social activities through face to face and using mobile phone media. The verbal communication is done to convey important messages in order to realize the implementation of Hinduism. Nonverbal communication in the implementation of religious social media using the letter, namely in the delivery of messages related to the implementation of religious ceremonies. Verbal and nonverbal communication conducted by Hindus in religious social activities is very concerned about ethics in communicating.

The ethics of communication in relation to religious social life in Hindu society in Banjar Dharma Santhi is based on the teachings of Hinduism, especially aspects of wacika parisudha. Communication process based on the teachings of wacika parisudha can realize good communication arrangement. Communications undertaken by the Hindu community at the site in addition to relating to the implementation of Hinduism is also used as a vehicle to convey messages to others, both individually and in groups. Communication based on the teachings of wacika parisudha become the foundation for the effort to realize harmonious society life. The harmony that occurs in the life of the community in Banjar Dharma Santhi not only with fellow Hindus but also with the general public who are in the vicinity of the location.

\section{Acknowledgments}

I would like to express my gratitude to the Chairman of State Hindu College (STAHN) Gde Pudja Mataram and his staff for for the opportunity to conduct research and competitive research funding that has been given. I would also like to thank the chairman and secretary of the Center for Research and Community Service for the information that has been given related to the research activities that are scheduled. To the informants who have been seriously providing data in accordance with the needs of the research also I thank you very much. I would like to express my gratitude to all those who have assisted in completing the research and writing of this paper. I hope that the results of this published study can be useful to all parties

Aryani, N. (2018). Implementation of Communication Ethics in Building Social Harmony. International Journal Of Social Sciences And Humanities (IJSSH), 2(1), 147-156. doi:10.29332/ijssh.v2n1.105 


\section{References}

1. Agus, B. (2006). Agama dalam Kehidupan Manusia: Pengantar Antropologi Agama. Rajagrafindo Persada (Rajawali Pers).

View in (Google Scholar)

2. Ahmad, H. H. A. Wadah Kerukunan.

View in (Google Scholar)

3. Atmaja, I. Made Nada, dkk. 2010. Etika Hindu. Surabaya: Paramita.

View in (Google Scholar)

4. Dewi, I. G. A. A. P., \& Dewi, P. P. (2018). Big Five Personality, Ethical Sensitivity, and Performance of Auditors. International Research Journal of Management, IT and Social Sciences (IRJMIS), 5(2), $195-209$.

View in (Google Scholar)

5. Effendy, O. U. (2008). Dinamika komunikasi. Remaja Rosdakarya.

View in (Google Scholar)

6. Gulo, W. (2002). Metodologi penelitian. Grasindo.

View in (Google Scholar)

7. Maswinara, I. W. (1998). Buku Pendidikan Agama Hindu untuk Perguruan Tinggi.

View in (Google Scholar)

8. Mulyana, D. (2000). Ilmu komunikasi: suatu pengantar. Remaja Rosdakarya.

View in (Google Scholar)

9. Naim, N. (2015). Self Development: Melejitkan Potensi Personal, Sosial, dan Spiritual. Yogyakarta: IAIN Tulungagung Press bekerjasama dengan Lentera Kreasindo.

View in (Google)

10. Pemayun, A. G. P., \& Brata, I. B. (2018). Implementation of Tourism Facilities Expansion to Hedonism and Community Imaging. International Journal of Social Sciences and Humanities (IJSSH), 2(1), 33-42.

View in (Google Scholar)

11. Santoso, E., \& Setiansah, M. (2010). Teori Komunikasi. Yogyakarta: Graha Ilmu.

View in (Google Scholar)

12. Subagiasta, I. K. (2007). Etika Pendidikan Agama Hindu. Surabaya: Paramita, 188.

View in (Google Scholar)

13.Suhardana, K. M. (2006). Pengantar Etika dan Moralitas Hindu: Bahan Kajian Untuk Memperbaiki Tingkah Laku. Surabaya: Paramita.

View in (Google Scholar)

14. Suhardana, K. M. (2011). Intropeksi Diri: Bahan Kajian Koreksi Diri Umat Hindu. Surabaya: Paramita. View in (Google Scholar) 
15. Suhardana. (2007). Tri Kaya Parisudha Bahan Kajian Berpikir Baik, Berkata Baik dan Berbuat Baik. Surabaya: Paramita.

View in (Google)

16. Sura, I. G. (1985). Pengendalian diri dan etika dalam ajaran agama Hindu.

View in (Google Scholar)

17.Wirawan, I. G. B. (2018). Surya Namaskara Benefits for Physical Health. International Journal of Social Sciences and Humanities (IJSSH), 2(1), 43-55.

View in (Google Scholar)

18. Wirawan, M. A. (2011). Tri Hita Karana (Kajian Teologi, Sosiologi dan Ekologi Menurut Veda). Surabaya: Paramita.

View in (Google Scholar)

Aryani, N. (2018). Implementation of Communication Ethics in Building Social Harmony. International Journal Of Social Sciences And Humanities (IJSSH), 2(1), 147-156. doi:10.29332/ijssh.v2n1.105 


\section{Biography of Author}

\begin{tabular}{|l|l||}
\hline Ni Luh Aryani was born in Nusa Penida, Bali, November 11 $1^{\text {th }, 1972 . ~ S h e ~ i s ~ a ~}$ \\
lecturer at State Hindu College (STAHN) Gde Pudja Mataram. Her office address at \\
Jl. Pancaka Number 7B Mataram, West Nusa Tenggara. She graduated her bachelor \\
degree in College Hindu Religious (STAH) Mataram. She finished her master \\
degree in Brahma Widya at Denpasar State Hindu Dharma Institute. \\
Email: luharyani1972@gmail.com
\end{tabular}

